\title{
18. CRETACEOUS FOSSIL WOOD FROM THE RAGGATT BASIN, SOUTHERN KERGUELEN PLATEAU (SITE 750) ${ }^{1}$
}

\author{
J. E. Francis ${ }^{2}$ and M. F. Coffin ${ }^{3}$
}

\begin{abstract}
Lower Cretaceous volcaniclastic sediments from Ocean Drilling Program Leg 120, Site 750, from the eastern flank of the Raggatt Basin on the Kerguelen Plateau, contain small clasts of fossil wood. Some wood is preserved as charcoal and has excellent structural preservation, whereas other wood is preserved as vitrinite with poor structure. All the wood examined is from conifer trees and is identified as Podocarpoxylon, wood similar to that of the living podocarps, and a type common in Antarctic and other Gondwanan Cretaceous floras. The presence of wood suggests that forested land was situated near the Raggatt Basin during the Early Cretaceous. Some wood was charred by burning in forest fires, possibly caused by volcanic eruptions. The charcoal and some unburnt wood was then buried in adjacent (probably nonmarine) sediments. This report provides an additional record of forest vegetation in high-latitude sites during the Cretaceous.
\end{abstract}

\section{INTRODUCTION}

Small pieces of fossil wood were observed in cores of probable terrestrial sediments of Cretaceous age from Ocean Drilling Program (ODP) Leg 120, Site 750 (Fig. 1). The wood was present as small blocks of a few millimeters diameter, some with black shiny surfaces and others with a dark brown matte luster, and was incorporated in grey/brown clayey siltstones or softpebble conglomerates of lithologic Unit IV (Fig. 2).

Fossil wood is common in Cretaceous terrestrial and shallow-marine sediments in Antarctica and, along with pollen, indicates that at that time Antarctica had a much warmer climate and was well vegetated. From the large sizes of the petrified logs and tree stumps on the Antarctic Peninsula (Jefferson, 1982; Francis, 1986), it is apparent that the vegetation consisted of dense forests with large forest trees, of types ancestral to living Southern Hemisphere vegetation. In the Early Cretaceous, the tree types were predominantly conifers and consisted mainly of podocarps and araucarians.

Wood is also preserved as small detrital clasts in clastic sediments, the fallen logs and twig litter having been broken up and incorporated into river sediments. Although such fragments reveal little about the original tree size or shape, they often retain anatomical detail, particularly if the wood has been burnt to charcoal, and can yield information about past environments and about the forest composition to complement pollen analyses. In this project the wood from Raggatt Basin was studied in terms of its composition, the taxonomic affinity of the wood types, and the environmental indications.

\section{GEOLOGICAL SETTING AND AGE}

The Kerguelen Plateau lies in the southern Indian Ocean approximately equidistant from Africa and Australia and

\footnotetext{
${ }^{1}$ Wise, S. W., Jr., Schlich, R., et al., 1992. Proc. ODP, Sci. Results, 120: College Station, TX (Ocean Drilling Program).

2 Department of Geology and Geophysics, University of Adelaide, P. O. Box 498, South Australia 5001, Australia (present address: Department of Earth Sciences, Leeds University, Leeds LS2 9JT, United Kingdom).

${ }^{3}$ Institute for Geophysics, The University of Texas at Austin, 8701 Mopac Blvd., Austin, TX 78759-8345, U.S.A. (formerly at Bureau of Mineral Resources Geology and Geophysics, P. O. Box 378, Canberra, ACT 2801, Australia).
}

about $1000 \mathrm{~km}$ from Antarctica. It is approximately $500 \mathrm{~km}$ wide and $2100 \mathrm{~km}$ long, with the long axis extending northwest-southeast (Fig. 1). The northern part of the plateau, which includes the volcanic Kerguelen and the Heard and McDonald islands, lies mostly less than $1000 \mathrm{~m}$ below sea level (mbsl) and extends south to $54^{\circ} \mathrm{S}$. The southern plateau lies deeper at $1000-3000 \mathrm{~m}$. The depth of the ocean basins surrounding the Kerguelen Plateau is generally $4000-4500 \mathrm{~m}$, except on its northeastern and southern flanks, where depths range from 3000 to $4000 \mathrm{~m}$, respectively. Two major sedimentary basins are known to exist on the Kerguelen Plateau: one on the northern sector between Kerguelen and Heard islands, and one on the Raggatt Basin in the southern sector. Of nine holes drilled into the Kerguelen Plateau during Legs 119 and 120 in 1988, three were situated in the Raggatt Basin, and two (748 and 750) of these three recovered Cretaceous sediments containing wood.

The fossil wood analyzed herein was recovered from Cores $120-750 \mathrm{~B}-12 \mathrm{~W}$ and $-13 \mathrm{~W}$ at Site 750 (Fig. 2). The sediment in these cores is a tough, plastic, ferruginous, kaolinitic, silty claystone. It includes a range of water-deposited terrigenous deposits from fine claystone to siltstone, with intervals richer in sand and even a soft-pebble conglomerate (Schlich, Wise, et al., 1989). Abundant coarse debris, including coal, other land-derived organic matter, and high concentrations of coarse sand-size authigenic siderite grains, pyrite grains, and concretions, are also present. The coal is present as detrital clasts rather than as continuous seams. The environmental interpretation is that of a basaltic platform in a subaqueous (probably nonmarine) environment, upon which red-brown volcanic weathering products were periodically deposited. The chemistry of the environment was acidic, probably a marsh. Woody material was abundant and, along with sedimentary indications of a nonmarine environment, suggests that it was transported only a short distance from the site of growth.

\section{FOSSIL WOOD}

\section{Sample Preparation}

The core samples were carefully broken apart to reveal wood fragments. Samples 120-750B-13W-1, 55-59 cm (C), and 120-750B-13W-1, 88-88 cm (B), contained charcoal and vitrinite; Sample 120-750B-13W-1, 40-42 cm (A), contained 


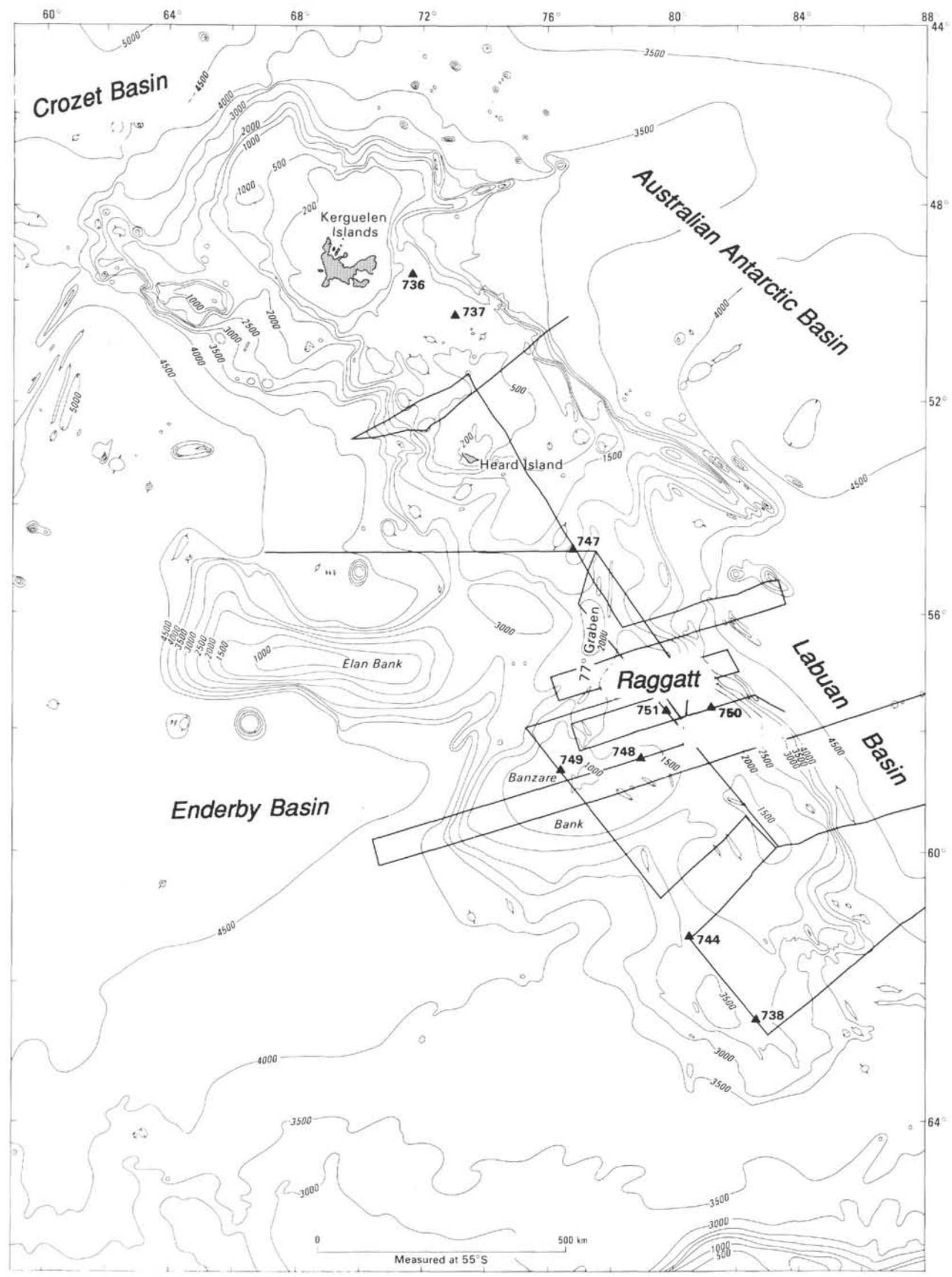

Figure 1. Bathymetry of the Kerguelen Plateau (after Schlich et al., 1987). Contour interval is $500 \mathrm{~m}$. Legs 119 and 120 drill sites appear as triangles. Black lines indicate multichannel seismic control. Samples for this study were collected at Site 750 on the eastern edge of the Raggatt Basin. 


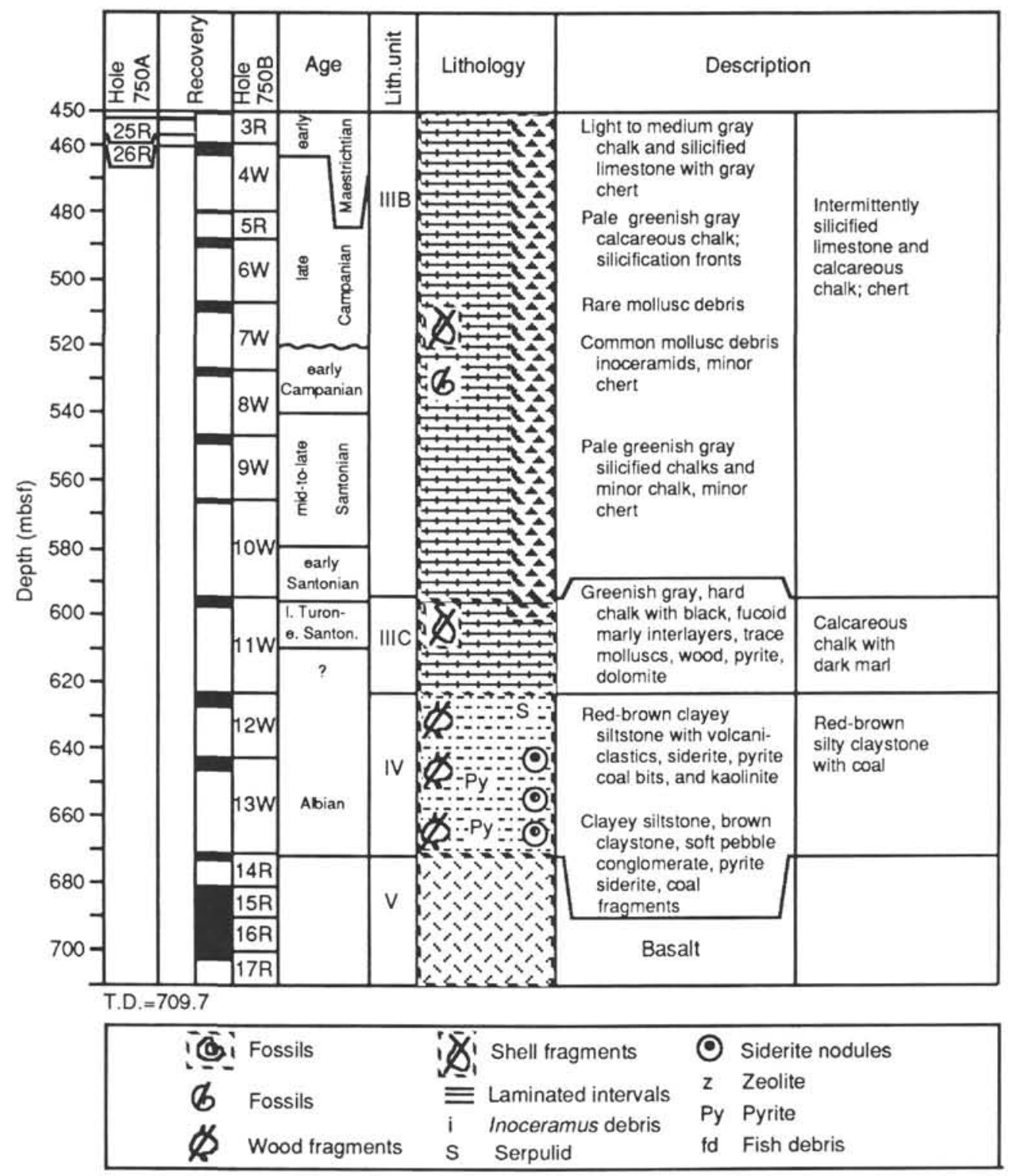

Figure 2. Cretaceous lithostratigraphy with wood sample locations, Site 750 (after Shipboard Scientific Party, 1989). Fossil wood used in this study was sampled from Cores 120-750B-12W and -13W. For more detailed sedimentary information see Holmes (this volume).

vitrinite only; Sample 120-750B-12W-3, 101-105 cm (D), contained charcoal; and Sample 120-750B-13W-3, 7-11 cm (E), contained finely broken fragments with very poor structure. The fragments were removed and cleaned by soaking in $10 \%$ $\mathrm{HCl}$ for $12 \mathrm{hr}$ and $5 \% \mathrm{HF}$ for $24 \mathrm{hr}$ to remove carbonate and silica minerals, followed by thorough washing in distilled water. The wood samples, which averaged $2-3 \mathrm{~mm}$ in diameter, were mounted on scanning electron microscope (SEM) stubs with acetone-based glue and coated with gold-palladium. We observed 17 wood samples. All observations were by scanning electron microscope.

\section{Preservation}

Fossil wood in the sediment cores is present as small blocks a few millimeters in diameter. During preliminary observations, it was apparent the wood had been preserved in two ways: as charcoal (fusinite) (Plate 1) and as vitrinite (Plate 2). This was confirmed by SEM observations.
Charcoalified wood, formed by burning, can be identified by a distinct set of features (Cope, 1980, 1981). These have been observed in some of the ODP specimens. The charcoalified wood is present as small rectangular blocks with a shiny, silky, black appearance; it leaves a black smear when crushed. Cellular preservation is excellent, and the only deformation features are of brittle fracture rather than plastic deformation or contortion. Cell lumina are empty (i.e., no mineral or organic infill of the cell (Plate 1, Fig. 4), but the cell walls have been homogenized so that individual cell-wall layers are no longer apparent (Plate 1, Fig. 4). Intercellular spaces (spaces between corners of adjacent cells) are present (Plate 1, Fig. 4).

Some specimens appear to be of compression wood, the strengthened wood that occurs on the underside of conifer branches to hold the branches up. These specimens have $\mathrm{S}$-shaped splits across the pits on the tracheids (Plate 1, Fig. 6), similar to "checks"' in living compression wood (Côté and 
Day, 1965). The helical splits follow the orientation of the fine microstructures on the $\mathrm{S}_{2}$ layer, one of the inner layers of the cell walls. It is apparent, therefore, that some of the fossil wood is from tree branches rather than from trunk or root wood.

In contrast, the vitrinite is present as irregular-shaped blocks, matte black or dark brown in color, and either shows faint traces of cell structure on the exterior or has a structureless texture. Under the SEM the cell structure is completely absent (Plate 2, Fig. 3) or is present but poor (Plate 2, Fig. 2). Cell walls are often deformed so that the cell apertures are closed and the cellular detail smeared (Plate 2, Fig. 1). This type of fossil wood generally forms from the burial of wood within sediments and subsequent water loss, gelification, and coalification (Stach et al., 1975). The survival of some degree of cellular detail, rather than being totally amorphous, implies that the wood has not undergone any significant amount of burial.

\section{Identification of the Wood}

Although the samples are very small, the excellent preservation of structural details in the charcoal has enabled the wood to be identified as conifer wood. The anatomical details in the vitrinite are poorly preserved, but they can be recognized as similar to those in the charcoal. Wood of angiosperms, which has a more complex structure with large vessels and different pitting, was not found.

The structurally preserved specimens show some variation in their anatomical details, but we consider them to be representative of natural variation within a single genus. The following description, therefore, encompasses all specimens: wood consisting of tracheids (vertical cells) that are rounded in outline (Plate 1, Fig. 1) and have single rows of circular pits on the radial walls (Plate 1, Fig. 6). No biseriate rows of pits or pitting on the tangential walls was observed (Plate 1, Fig. 9). Wood rays consist of horizontal cells crossing tracheids in radial direction (Plate 1, Fig. 3); the rays are from 2 to 9 cells deep and one cell wide (uniseriate) (Plate 1, Fig. 7). The radial walls of the ray cells contain from 1 to 3 cross-field pits, which connect them with each tracheid cell (Plate 1, Figs. 2, 5, and 8 ). The cross-field pits are $7-10 \mu \mathrm{m}$ in diameter and have inclined, oblique apertures enclosed by borders. The horizontal and tangential walls of the ray cells appear to be smooth. No resin canals apparent.

\section{Affinities}

The small size of the samples did not permit detailed identification or formal taxonomic description of the wood. The nature of the pitting in the ray cells is an important feature. In these samples there are 1-3 pits per cross-field with inclined elliptical apertures. Some are of podocarp-type (narrow borders) and some of cupressus-type (wider borders), both occurring within the same specimen. A few large elliptical pits without borders were also observed. The variation in pitting seen in these fossil specimens and other features of the anatomy are encompassed within the living species of Podocarpus described by Patel (1967) and Greguss (1955).

Fossil wood resembling that of living Podocarpaceae can be assigned to the form-genus Podocarpoxylon Stopes (1915). Many fossil woods of this type are named as Mesembrioxylon, a form-genus erected by Seward (1919) to avoid affinity with any living genus, although some woods placed in this formgenus do have podocarpaceous characteristics. However, in this case the name Podocarpoxylon is preferred because the fossil wood from the Raggatt Basin does have features characteristic of living Podocarpaceae.
Some of the members of the Cupressaceae have very similar features to the podocarps and, likewise, the wood of Podocarpoxylon and Cupressinoxylon is often indistinguishable. Therefore, it is possible that cupressus-type wood is present here (pollen grains of the Cupressaceae are present in this Kerguelen material; Mohr and Gee, Chapter 19, this volume). However, there is not sufficient detail preserved in the fossil wood to warrant separation into two form-genera, and it is considered here only valid to use Podocarpoxylon.

\section{DISCUSSION}

The presence of fossil wood within the volcaniclastic sediments of the Raggatt Basin implies that forested land existed in close proximity during the Early Cretaceous. Within those forests podocarp conifers were an important part of the vegetation. Bisaccate grains of podocarp conifers are also common in the sediment; based on terrestrial sporomorphs, the age of the sequence containing the fossil wood is early Albian or $\sim 110 \mathrm{Ma}$ (Mohr and Gee, Chapter 17, this volume), according to the time scale of Kent and Gradstein (1985).

The presence of fossil charcoal as detrital clasts in the Raggatt Basin sediments indicates that the trees were burnt in the forests, and the charcoal subsequently washed down into adjacent depositional sites. A common cause of ancient forest fires was probably lightning (Cope, 1980; Cope and Chaloner, 1985); however, in a volcanically active environment, it seems likely that some fires were started by volcanic eruptions. Once wood has been charred, it becomes very resistant to microbial decay or permineralization. The additional presence of vitrinite indicates that some unburnt wood was also buried in the sediments; this association is not uncommon (Cope, 1981).

Similar environments were also present at approximately the same time in the Antarctic Peninsula region. During the Cretaceous, the Peninsula was an emergent and active volcanic arc that was covered with dense forests (Francis, 1986). Logs from the forest trees were washed into the rivers and then into shallow-marine volcaniclastic sediments in the Larsen backarc basin to the east and, in this case, were mostly permineralized. However, at Table Nunatak on the Larsen ice shelf, charcoalified seeds and twigs are preserved within river channel sediments, again implying that the Antarctic Peninsula forests were burnt by fires (J. E. Francis, D. I. Macdonald, and J. Riding, pers. comm., 1990).

Podocarps were a very common component of Gondwanan floras, including those from high-latitude sites, and were present in Antarctica, South America, South Africa, and Australasia. Their pollen is present in many Cretaceous and Tertiary pollen assemblages from Australia (Morgan, 1980) and Antarctica, including those from the Antarctic Peninsula (Askin, 1983; Dettman and Thomson, 1987) and those from marine offshore basins (Truswell, 1983; Truswell and Drewry, 1984). Today podocarps are present in all these southern continents and have also spread to more tropical latitudes in Southeast Asia (Hair, 1965).

Macrofossils of podocarps are also present as large fossil trees in Lower Cretaceous sediments of Australia (Frakes and Francis, 1990) and Lower and Upper Cretaceous nonmarine and shallow-marine sediments of the Antarctic Peninsula and adjacent islands (Francis, 1986) (Fig. 3). The climates of the Antarctic and Kerguelen regions were clearly much warmer than those at present, even though paleomagnetic results (Inokuchi and Heider, Chapter 7, this volume) and plate tectonic syntheses (e.g., Norton and Sclater, 1979) indicate that they were situated at high latitudes since at least Early Cretaceous time (Fig. 4). Analysis of growth rings in the fossil wood from the Peninsula region shows that the climate was 


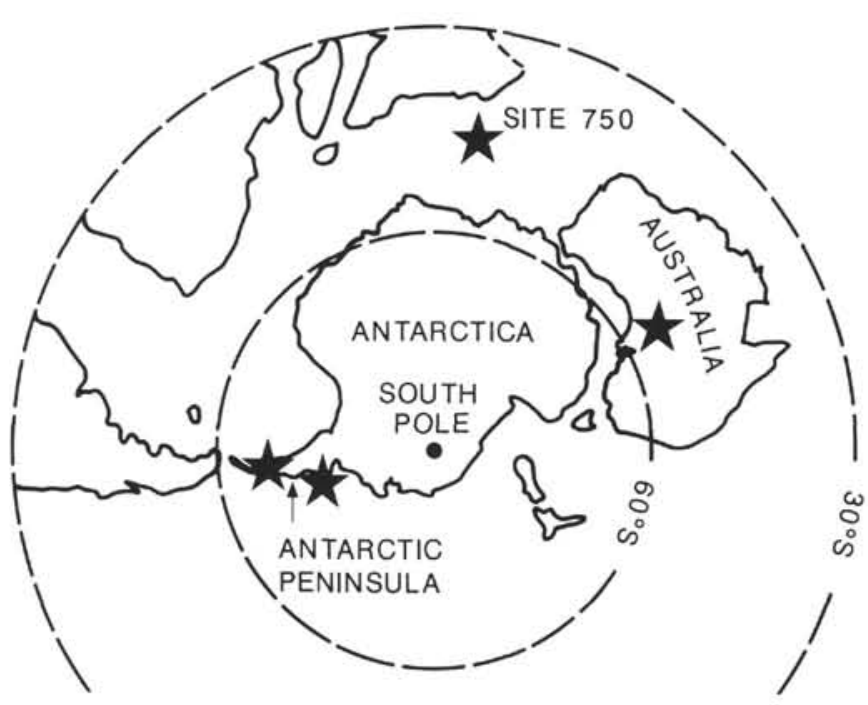

Figure 3. Paleogeographic map to show location of fossil forests (represented by stars) with fossil podocarp wood on the Antarctic Peninsula and in central Australia, mentioned in the text and compared to the wood from Site 750 . Reconstruction for $100 \mathrm{Ma}$ from Smith et al. (1981).

cool to warm temperate and very favorable for forest growth, even though the area was situated in latitudes greater than $80^{\circ} \mathrm{S}$ (Jefferson, 1982; Francis, 1986).

\section{SUMMARY}

Small fragments of fossil wood incorporated in Cretaceous volcaniclastic claystones from Leg 120 , Site 750 , on the edge of the Raggatt Basin, consist of charcoalified and coalified conifer wood. Their presence indicates that forested land occurred close to the margins of the basin and that forest fires occasionally burnt some of the trees. Identification of the fossil wood indicates that podocarp conifers were a major component of the forest vegetation, similar to Cretaceous forests on the Antarctic Peninsula and in Australia.

\section{ACKNOWLEDGMENTS}

We thank Pat Quilty and Woody Wise for encouraging this study, and all Leg 120 participants aboard JOIDES Resolution for obtaining the samples. M. F. Coffin publishes with the permission of the Director, Bureau of Mineral Resources, Geology and Geophysics, Canberra, Australia (UTIG contribution No. 829). J. E. Francis is grateful for research facilities provided by The University of Adelaide.

\section{REFERENCES}

Askin, R. A., 1983. Tithonian (Uppermost Jurassic)-Barremian (Lower Cretaceous) spores, pollen and microplankton from the South Shetland Islands, Antarctica. In Oliver, R. L., James, P. R., and Jago, J. B. (Eds.), Antarctic Science: Canberra (Australian Academy of Science), 295-297.

Cope, M. J., 1980. Physical and chemical properties of coalified and charcoalified phytoclasts from some British Mesozoic sediments: an organic geochemical approach to palaeobotany. In Douglas, A. G., and Maxwell, J. R. (Eds.), Advances in Organic Geochemistry, 1979: Oxford (Pergamon Press), 883-887.
1981. Products of natural burning as a component of the dispersed organic matter in sedimentary rocks. In Brooks, J. (Ed.), Organic Maturation Studies and Fossil Fuel Exploration: London (Academic Press), 89-109.

Cope, M. J., and Chaloner, W. G., 1985. Wildfire: an interaction of biological and physical processes. In Tiffney, B. H. (Ed.), Geological Factors and the Evolution of Plants: New Haven, CT (Yale Univ. Press), 257-277.

Côté, W. A., and Day, A. C., 1965. Anatomy and ultrastructure of reaction wood. In Côté, W. A. (Ed.), Cellular Ultrastructure of Woody Plants: Syracuse, NY (Syracuse Univ. Press), 391418.

Dettman, M. E., and Thomson, M.R.A., 1987. Cretaceous palynomorphs from the James Ross Island area, Antarctica-a pilot study. Brit. Antarc. Surv. Bull., 77:13-59.

Frakes, L. A., and Francis, J. E., 1990. Cretaceous climates. In Ginsburg, R. N., and Beaudoin, B. (Eds.), Cretaceous Resources, Events and Rhythms: Dordrecht, The Netherlands (Kluwer Academic Publishers), 273-287.

Francis, J. E., 1986. Growth rings in Cretaceous and Tertiary fossil wood from Antarctica and their palaeoclimatic implications. Palaeontology, 29:685-884.

Greguss, P., 1955. Identification of Living Gymnosperms on the Basis of Xylotomy: Budapest (Akademiai Kiado).

Hair, J. B., 1965. Cytogeographic relationships of the southern podocarps. In Darlington, P. J. (Ed.), Biogeography of the Southern End of the World: Cambridge, MA (Harvard Univ. Press), 401-414.

Jefferson, T. H., 1982. Fossil forests from the Lower Cretaceous of Alexander Island, Antarctica. Palaeontology, 25:891-708.

Kent, D. V., and Gradstein, F., 1985. A Cretaceous and Jurassic geochronology. Geol. Soc. Am. Bull., 98:1419-1427.

Morgan, R., 1980. Palynostratigraphy of the Australian Early and Middle Cretaceous. Geol. Surv. N.S.W., Palaeontol. Mem., No. 18.

Norton, I. O., and Sclater, J. G., 1979. A model for the evolution of the Indian Ocean and the break-up of Gondwanaland. J. Geophys. Res., 84:6803-6830.

Patel, R. N., 1967. Wood anatomy of the Podocarpaceae indigenous to New Zealand. 2. Podocarpus. N. Z. J. Bot., 5:307-321.

Schlich, R., Coffin, M., Munschy, M., Stagg, H.M.J., Li, Z. G., and Revill, K., 1987. Bathymetric Chart of the Kerguelen Plateau. [Jointly edited by Bureau of Mineral Resources, Geology and Geophysics, Canberra, Australia; Institut de Physique du Globe, Strasbourg, France; and Terres Australes et Antarctiques Francaises, Paris, France.]

Seward, A. C., 1919. Fossil Plants (Vol. IV): London (Cambridge Univ. Press).

Shipboard Scientific Party, 1989. Site 750. In Schlich, R., Wise, S. W., Jr., et al., Proc. ODP, Init. Repts., 120: College Station, TX (Ocean Drilling Program), 277-337.

Smith, A. G., Hurley, A. M., and Briden, J. C., 1981. Phanerozoic Paleocontinental World Maps: Cambridge (Cambridge Univ. Press).

Stach, E., Mackowsky, M. T., Teichmüller, M., Taylor, G. H., Chandra, D., and Teichmüller, R., 1975. Stach's Textbook of Coal Petrology: Berlin (Gebruder Borntraeger).

Stopes, M. C., 1915. Catalogue of Mesozoic Plants in the British Museum (Natural History) (Part 2): London (British Museum).

Truswell, E. M., 1983. Recycled Cretaceous and Tertiary pollen and spores in Antarctic marine sediments: a catalogue. Palaeontographica, Abt. B., 186:121-174.

Truswell, E. M., and Drewry, D. J., 1984. Distribution and provenance of recycled palynomorphs in surficial sediments of the Ross Sea, Antarctica. Mar. Geol., 59:187-214.

Date of initial receipt: 18 January 1990

Date of acceptance: 4 December 1990

Ms 120B-195 


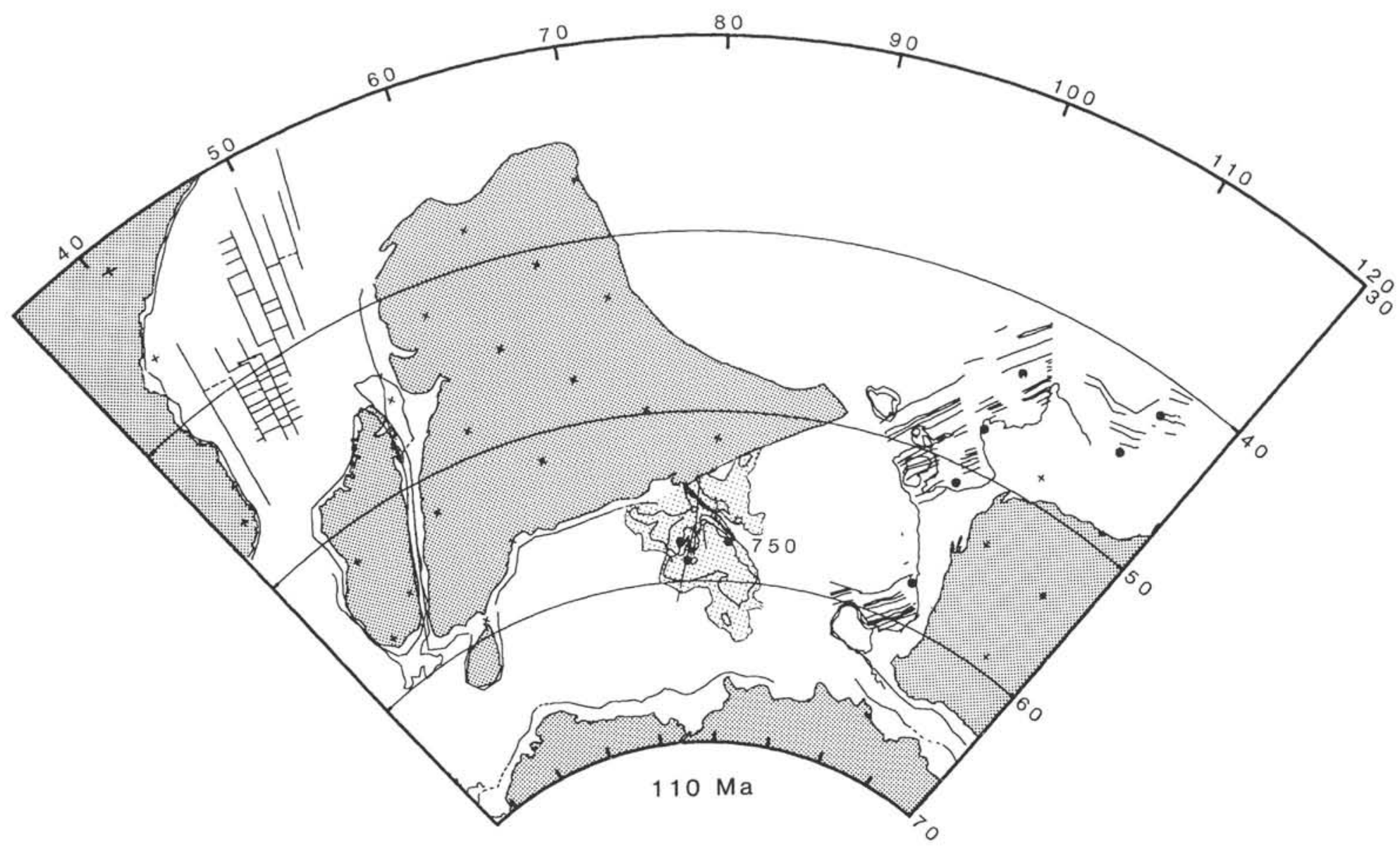

Figure 4. Reconstruction to show the position of Site 750 during Early Albian time (110 Ma) with Antarctica fixed (after Royer and Coffin, this volume). 


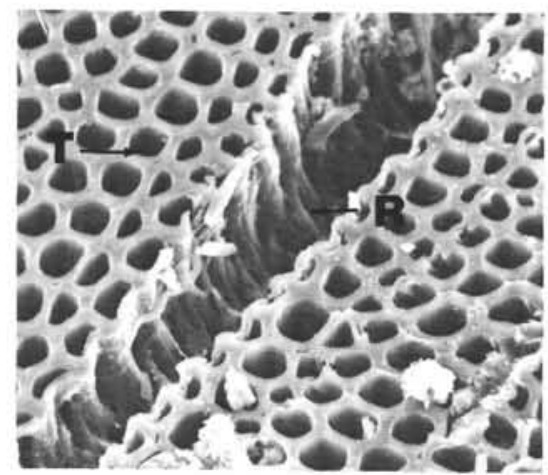

1

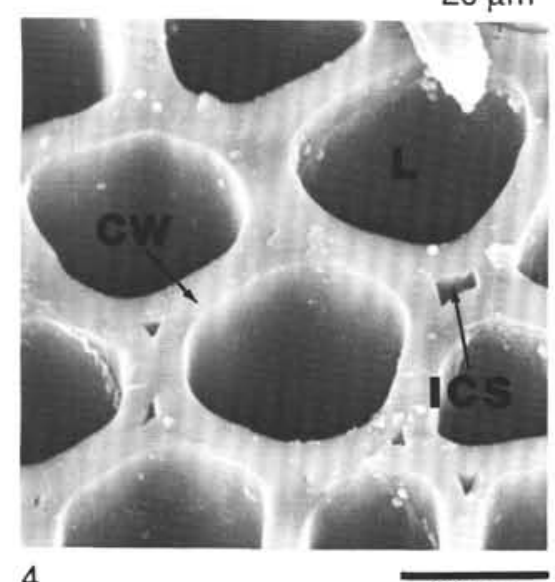

4

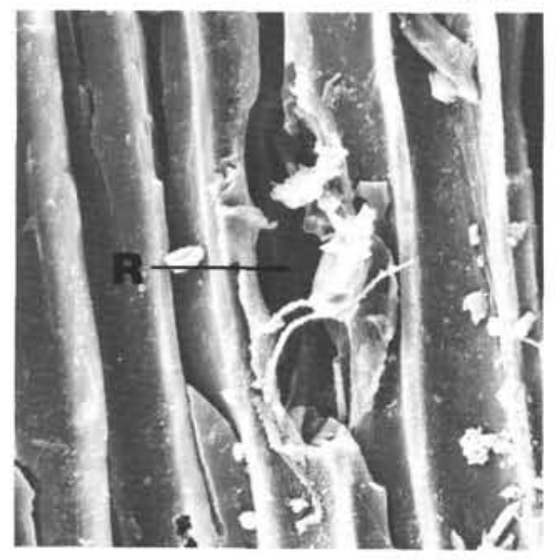

7

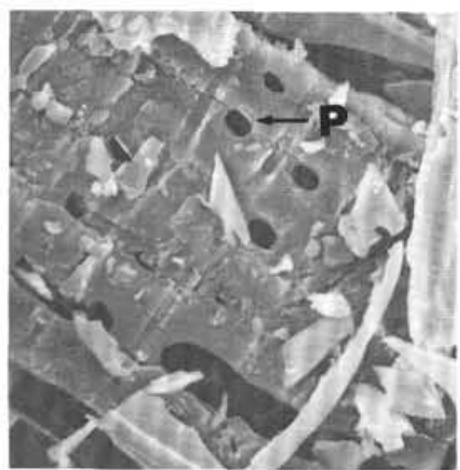

2

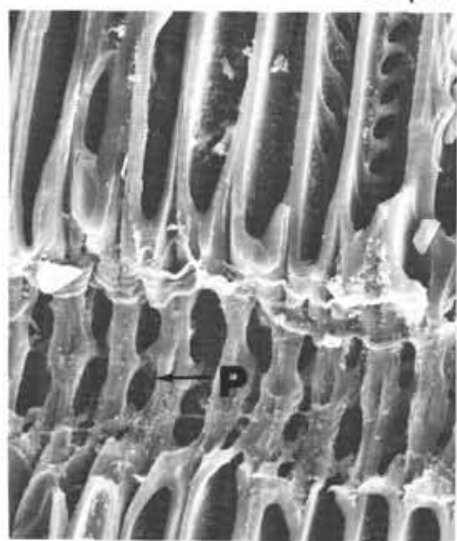

5

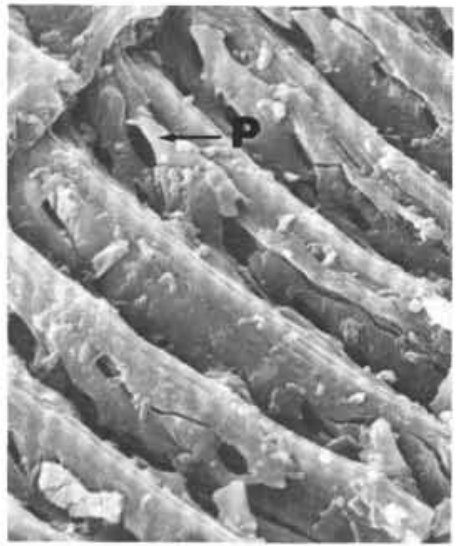

8

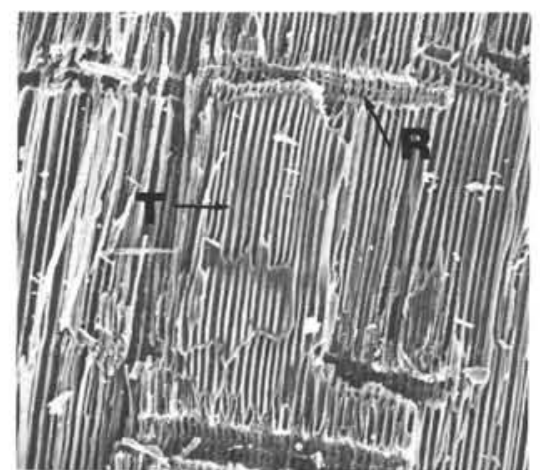

3

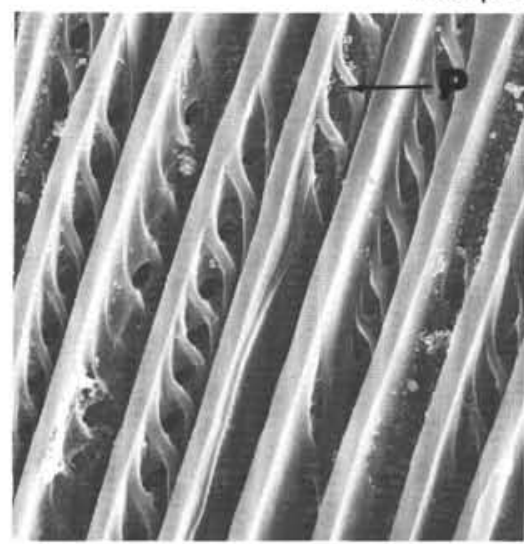

6

$1 \overline{\mu \mathrm{m}}$

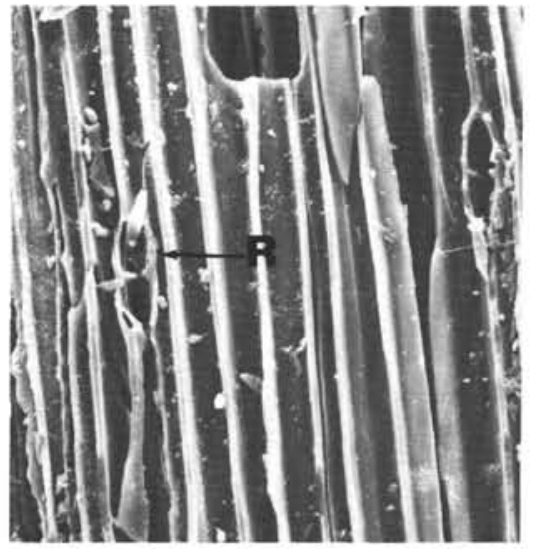

9

$\overline{50 \mu \mathrm{m}}$

Plate 1. SEM photomicrographs of early Cretaceous charcoalified wood of Podocarpoxylon, from the eastern flanks of the Raggatt Basin. 1. Sample 120-750B-13W-1, 55-59 cm (Cl); transverse section showing ray (R) crossing tracheids (T). 2. Sample 120-750B-12W-3, 101-105 cm (D3); radial section showing pit (P) with elliptical aperture and narrow borders in cross-field between ray cell and tracheid. 3. Sample 120-750B-13W-1, 55-59 cm (Cl); radial section showing rays (R) crossing vertical tracheids (T). 4. Sample 120-750B 13W-1, $55-59 \mathrm{~cm}(\mathrm{Cl})$; transverse section showing features typical of charcoal: intercellular spaces (ICS), homogenized cell walls (CW), and empty lumen (L). 5. Sample 120-750B-13W-1, 55-59 cm (Cl); radial section showing large open pit (P) between ray cell and tracheid. 6. Sample 120-750B-13W-1, 55-59 cm (Cl); radial section showing single rows of pits $(\mathrm{P})$ on radial walls of tracheids. 7. Sample $120-750 \mathrm{~B}-13 \mathrm{~W}-1,55-59 \mathrm{~cm}(\mathrm{Cl})$; tangential section showing ray cell $(\mathrm{R})$ three cells deep. 8. Sample 120-750B-13W-1, 40-42 cm (Al); radial section showing ray cell with $1-3$ elliptical pits $(\mathrm{P})$ per cross-field. 9. Sample $120-750 \mathrm{~B}-13 \mathrm{~W}-1,55-59 \mathrm{~cm}(\mathrm{Cl})$; section showing smooth tangential tracheid walls; ray cells $(R)$. 


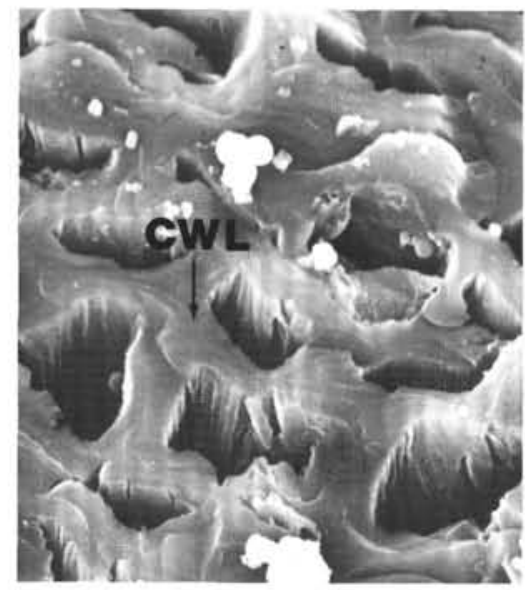

1

$\overline{10 \mu \mathrm{m}}$

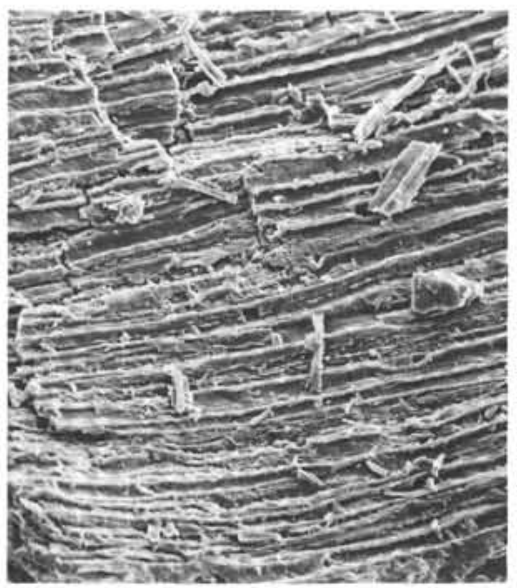

2

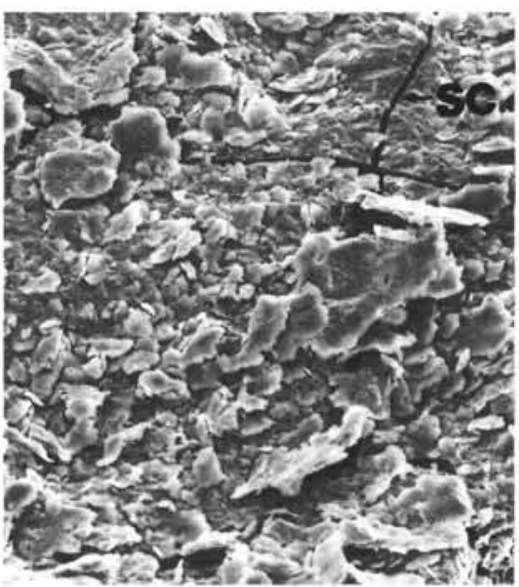

3

Plate 2. SEM photomicrographs of early Cretaceous wood from the eastern flanks of the Raggatt Basin preserved as vitrinite. 1. Sample 120-750B-13W-1, 55-59 cm (C2); transverse section across cells showing contorted, deformed cell walls; layers of the cell walls are still visible (CWL). 2. Sample 120-750-13W-3, 7-11 cm (E2); tangential section showing that cell walls are still distinct but other features, such as pitting, are not apparent. 3. Sample 120-750B-13W-3, 7-11 cm (E3); very poorly preserved wood with no cellular detail; shrinkage cracks (SC) are apparent. 